Article

\title{
Production of Bioethanol from Carrot Pomace Using the Thermotolerant Yeast Kluyveromyces marxianus
}

\author{
Chi-Yang Yu, Bo-Hong Jiang and Kow-Jen Duan *
}

Department of Bioengineering, Tatung University, 40 Chungshan N. Rd. Sec. 3, Taipei 10452, Taiwan; E-Mails: chrisyu@ttu.edu.tw (C.-Y.Y.); hk12737goddlesss@yahoo.com (B.-H.J.)

* Author to whom correspondence should be addressed; E-Mail: duan@ttu.edu.tw; Tel.: +886-2-2182-2928 (ext. 6318); Fax: +886-2-2585-4735.

Received: 8 October 2012; in revised form: 20 December 2012 / Accepted: 8 March 2103 / Published: 21 March 2013

\begin{abstract}
Carrot pomace, a major agricultural waste from the juice industry, was used as a feedstock for bioethanol production by fermentation with the thermotolerant yeast Kluyveromyces marxianus. Treatment of the carrot pomace with Accellerase ${ }^{\mathrm{TM}} 1000$ and pectinase at $50{ }^{\circ} \mathrm{C}$ for $84 \mathrm{~h}$, resulted in conversion of $42 \%$ of its mass to fermentable sugars, mainly glucose, fructose, and sucrose. Simultaneous saccharification and fermentation (SSF) at $42{ }^{\circ} \mathrm{C}$ was performed on $10 \%(w / v)$ carrot pomace; the concentration of ethanol reached $18 \mathrm{~g} / \mathrm{L}$ and the yield of ethanol from carrot pomace was $0.18 \mathrm{~g} / \mathrm{g}$. The highest ethanol concentration of $37 \mathrm{~g} / \mathrm{L}$ was observed with an additional charge of $10 \%$ supplemented to the original $10 \%$ of carrot pomace after $12 \mathrm{~h}$; the corresponding yield was $0.185 \mathrm{~g} / \mathrm{g}$. Our results clearly demonstrated the potential of combining a SSF process with thermotolerant yeast for the production of bioethanol using carrot pomace as a feedstock.
\end{abstract}

Keywords: bioethanol; carrot pomace; Kluyveromyces marxianus; simultaneous saccharification and fermentation

\section{Introduction}

In recent years, bioethanol has drawn an immense amount of attention as a clean, safe, and renewable alternative energy source because of the exhaustion of fossil fuels and ever-increasing air pollution. It is by far the most widely used biofuel for transportation worldwide [1]. Production of 
bioethanol from renewable biomass will reduce the environmental pollution and postpone the depletion of crude oil.

Sugar-containing, starch-containing, and lignocellulosic materials are often used as feedstocks for the production of bioethanol. Common feedstocks include sugarcane, sugar beet, corn, and wheat. Compared to other feedstock materials, lignocellulosic materials offer several unique and desirable features such as a secure source of supply, limited conflict with land use for food and feed production, and low fossil fuel inputs [1]. Common sources of lignocellulosic materials include crop residues, forest residues, and municipal solid waste [2].

Carrot pomace is a lignocellulosic material produced in large quantities during the process of juice extraction in the industry. Although this agricultural residue may be used as an animal feed, it is usually discarded as waste [3]. Juice processing companies produce about six thousand tons of carrot pomace annually in Taiwan (personal communication). Carrot pomace is composed of $28 \%$ cellulose, $2.1 \%$ pectin, $6.7 \%$ hemicellulose, and $17.5 \%$ lignin on dry weight basis [4]. Bioethanol production with carrot pomace as a feedstock using a separate hydrolysis and fermentation (SHF) process has been reported in other studies [5].

We explored the potential of bioethanol production from carrot pomace using a simultaneous saccharification and fermentation (SSF) process in combination with a thermotolerant yeast. The major advantage of SSF over SHF is the higher rate of ethanol production because the cellulase-inhibiting glucose, product from the saccharification of biomass, is rapidly converted to ethanol by the yeast [6]. Additionally, only one bioreactor is required for SSF which leads to lower cost. However, a major drawback of the SSF process is that the operating conditions are often compromises between saccharification and fermentation. For instance, the enzymatic hydrolysis has an optimum temperature around $50{ }^{\circ} \mathrm{C}$ but most fermenting microorganisms have an optimum temperature between $30{ }^{\circ} \mathrm{C}$ and $37{ }^{\circ} \mathrm{C}$. We used a thermotolerant yeast, Kluyveromyces marxianus, which grows rapidly even at temperatures above $40{ }^{\circ} \mathrm{C}$, to improve the yield of ethanol with the SSF process [7]. Additional advantages of using a thermotolerant yeast include higher saccharification yields, decreased risk of contamination, and the possibility of continuous ethanol removal [7]. In this study, the compositions of fermentable sugars of the hydrolysate from carrot pomace were determined, and then different fermentation strategies were applied to improve the concentration and yield of ethanol with the SSF process.

\section{Results and Discussion}

\subsection{Composition of the Hydrolysate from Carrot Pomace}

Three major sugars, glucose, fructose, and sucrose, were identified in the hydrolysate and their concentrations were 12,3 , and $6 \mathrm{~g} / \mathrm{L}$, respectively, after treatment of 5\% $(w / v)$ carrot pomance with Accellerase $^{\mathrm{TM}} 1000$ and pectinase. The amount of these fermentable sugars accounted for $42 \%(w / w)$ of the carrot pomace. The concentrations of the fermentable sugars showed little change after increasing the doses of Accellerase ${ }^{\mathrm{TM}} 1000$ and pectinase, which indicated that almost all the fermentable sugars were released from the carrot pomace. 


\subsection{SSF of Carrot Pomace Using Different Fermentation Strategies}

The results of the SSF process with $10 \%(w / v)$ carrot pomace as a feedstock are shown in Figure 1. After $24 \mathrm{~h}$, the ethanol concentration reached a plateau of $18 \mathrm{~g} / \mathrm{L}$ and almost all the glucose was consumed. The yield of ethanol from the carrot pomace was $0.18 \mathrm{~g} / \mathrm{g}$ (maximum mass of ethanol produced/mass of substrate added). When an additional $5 \%(w / v)$ of the carrot pomace was supplemented to the initial charge of $10 \%(w / v)$ at $12 \mathrm{~h}$, the concentration of ethanol increased to $30 \mathrm{~g} / \mathrm{L}$ at $36 \mathrm{~h}$, and a slight increase in glucose was observed after $48 \mathrm{~h}$ (Figure 2).

Figure 1. Time course of ethanol $(\square)$, glucose $(\bullet)$, fructose $(\circ)$, and sucrose $(\boldsymbol{\nabla})$ during the SSF process with $10 \%(w / v)$ carrot pomace as the feedstock.

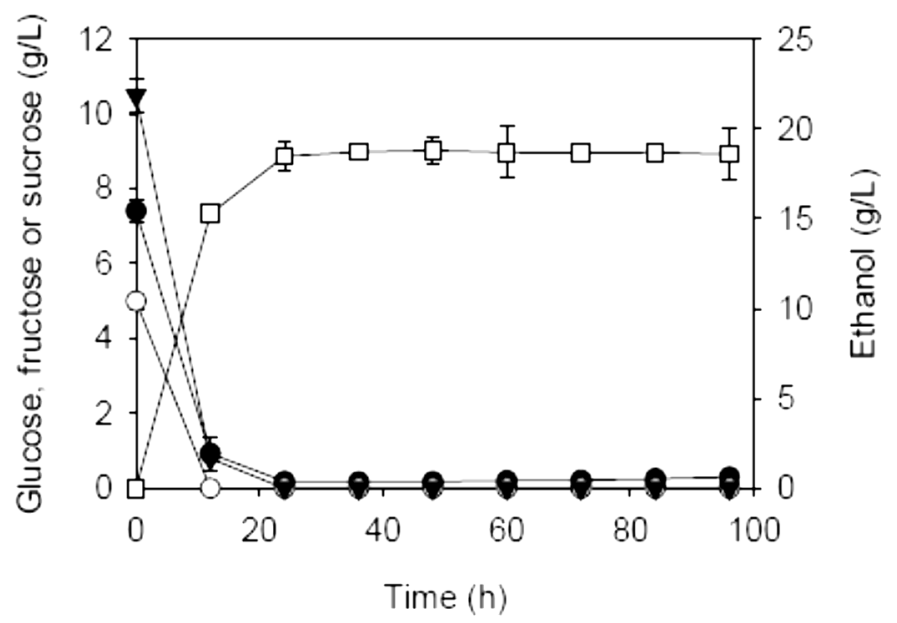

Figure 2. Time course of ethanol $(\square)$, glucose $(\bullet)$, fructose $(\circ)$, and sucrose $(\boldsymbol{\nabla})$ during the SSF process with $15 \%(w / v)$ carrot pomace as the feedstock. The initial carrot pomace charge was $10 \%(w / v)$ and an additional 5\% $(w / v)$ was added at $12 \mathrm{~h}$.

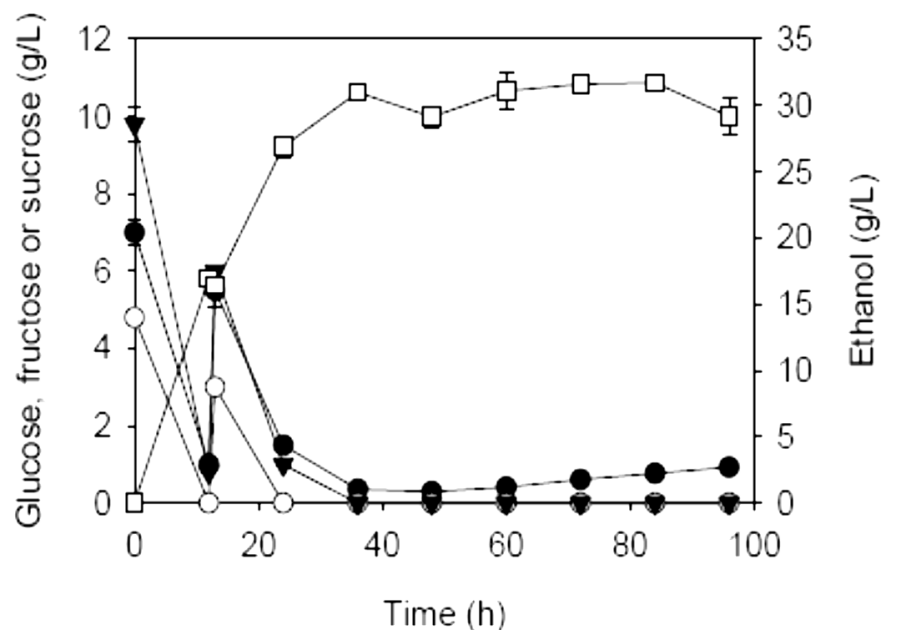

The increase in glucose could be explained by the low viability of the thermotolerant yeast because of high ethanol concentration; few viable yeast cells were found as determined with a methylene-blue based viability assay. The growth inhibition of Kluyveromyces sp. by ethanol has been reported [8]; devices such as an air stripper has been employed to remove ethanol from the fermenter to alleviate its 
toxic effects [9]. When two additions of 5\% $(w / v)$ carrot pomace were supplemented at 12 and $18 \mathrm{~h}$ to the initial charge of $10 \%(w / v)$; however, such a strategy had little effect on the concentration of ethanol, which reached $32 \mathrm{~g} / \mathrm{L}$ at $36 \mathrm{~h}$ (Table 1). Addition of $10 \%(w / v)$ of the carrot pomace to the initial charge at $12 \mathrm{~h}$ resulted in the highest ethanol concentration of $37 \mathrm{~g} / \mathrm{L}$ after $42 \mathrm{~h}$ (Figure 3), which was significantly higher than $28 \mathrm{~g} / \mathrm{L}$ reported by Patle and Lal using a SHF process [5]. The accumulation of glucose after $60 \mathrm{~h}$ was also observed.

Table 1. Maximum ethanol $(\mathrm{EtOH})$ concentrations, yields $\left(Y_{\mathrm{E} / \mathrm{S}}\right)$, and productivities with carrot pomace as a feedstock using different fermentation strategies.

\begin{tabular}{|c|c|c|c|c|c|c|c|}
\hline \multirow{2}{*}{$\begin{array}{c}\text { Initial charge } \\
\text { of carrot pomace } \\
(\%, w / v) \\
\end{array}$} & \multicolumn{2}{|c|}{$\begin{array}{l}\text { Addition } \\
(\%, w / v)\end{array}$} & \multirow{2}{*}{$\begin{array}{l}\text { Prehydrolysis dosages } \\
\text { of Accellerase }{ }^{\mathrm{TM}} 1000 \\
\text { (FPU/g dry matter) \& } \\
\text { pectinase (U/g dry matter) }\end{array}$} & \multirow{2}{*}{$\begin{array}{l}\text { Max. } \\
\text { EtOH } \\
(\mathrm{g} / \mathrm{L})\end{array}$} & \multirow{2}{*}{$\begin{array}{c}\text { Theoretical } \\
\text { max. EtOH } \\
\qquad(\mathrm{g} / \mathrm{L})^{\mathrm{a}}\end{array}$} & \multirow{2}{*}{$\begin{array}{c}Y_{E / S} \\
(g / g)^{b}\end{array}$} & \multirow{2}{*}{$\begin{array}{c}Q_{\mathrm{E}} \\
(\mathrm{g} / \mathrm{L} \cdot \mathbf{h})^{\mathrm{c}}\end{array}$} \\
\hline & $t=12 \mathrm{~h}$ & $t=18 \mathrm{~h}$ & & & & & \\
\hline 10 & & & - & 18 & 21.2 & 0.18 & $0.75(24 \mathrm{~h})$ \\
\hline 10 & 5 & & - & 30 & 32.2 & 0.2 & $0.83(36 \mathrm{~h})$ \\
\hline 10 & 5 & 5 & - & 32 & 42.8 & 0.16 & $0.89(36 \mathrm{~h})$ \\
\hline 10 & 10 & & - & 37 & 42.8 & 0.185 & $0.88(42 \mathrm{~h})$ \\
\hline 10 & & & $15 \& 52.3$ & 18 & 21.4 & 0.18 & $0.75(24 \mathrm{~h})$ \\
\hline 10 & 10 & & $7.5 \& 26.2$ & 30 & 42.8 & 0.15 & $0.83(36 \mathrm{~h})$ \\
\hline 20 & & & $15 \& 52.3$ & 15 & 42.8 & 0.075 & $0.21(72 \mathrm{~h})$ \\
\hline
\end{tabular}

${ }^{a}$ Theoretical max. EtOH $(\mathrm{g} / \mathrm{L})=$ substrate concentration $(\mathrm{g} / \mathrm{L}) \times 0.42$ (weight percentage of fermentable sugars $) \times 0.51 ;{ }^{\mathrm{b}} Y_{\mathrm{E} / \mathrm{S}}(\mathrm{g} / \mathrm{g})=$ mass of $\mathrm{EtOH}(\mathrm{g}) /$ mass of substrate $(\mathrm{g}) ;{ }^{\mathrm{c}} Q_{\mathrm{E}}(\mathrm{g} / \mathrm{L} \cdot \mathrm{h})$ $(\mathrm{EtOH}$ productivity $)=\mathrm{Max} \mathrm{EtOH}(\mathrm{g} / \mathrm{L}) /$ time to reach max. EtOH (in parentheses).

Figure 3. Time course of ethanol $(\square)$, glucose $(\bullet)$, fructose $(\circ)$, and sucrose $(\boldsymbol{\nabla})$ during the SSF process with $20 \%(w / v)$ carrot pomace as the feedstock. The initial carrot pomace charge was $10 \%(w / v)$ and an additional $10 \%(w / v)$ was added at $12 \mathrm{~h}$.

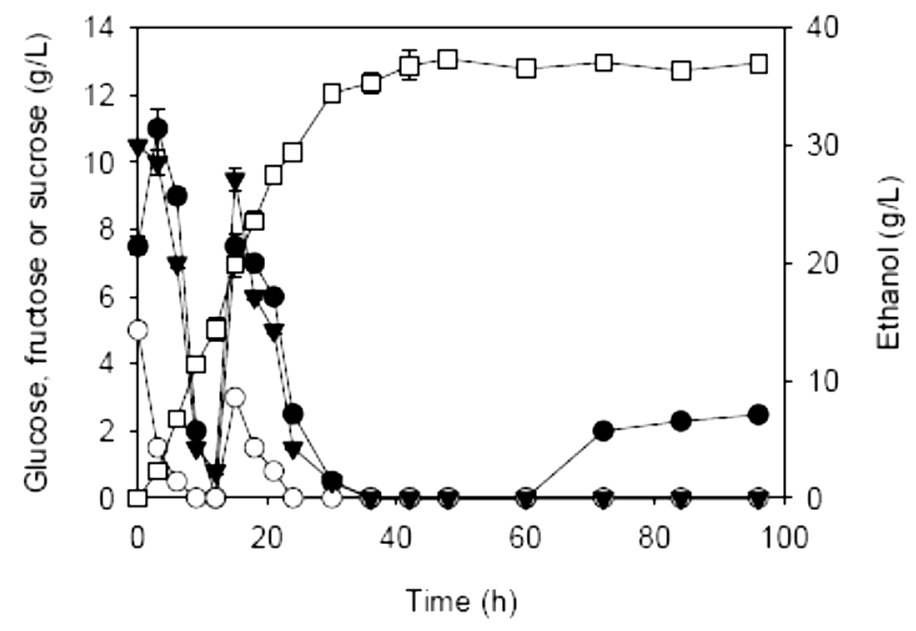

\subsection{Effects of Enzymatic Prehydrolysis}

Enzymatic prehydrolysis prior to SSF can decrease the viscosity of the fermentation sludge, and thus improve the mass and heat transfer; making the subsequent SSF shorter and compatible with even higher water insoluble substances [10]. Prehydrolysis was performed for $12 \mathrm{~h}$ on $10 \%(w / v)$ carrot 
pomace at $50{ }^{\circ} \mathrm{C}$ (for the doses of Accellerase ${ }^{\mathrm{TM}} 1000$ and pectinase, see Section 3.4); the time course of ethanol concentration showed little change as compared to that without prehydrolysis. When an additional $10 \%$ substrate was supplemented to the initial $10 \%(w / v)$ of carrot pomace prehydrolyzed for $12 \mathrm{~h}$; the maximum ethanol concentration of $30 \mathrm{~g} / \mathrm{L}$ was reached after $36 \mathrm{~h}$, which was lower than the $37 \mathrm{~g} / \mathrm{L}$ (at $42 \mathrm{~h}$ ) obtained after SSF process without prehydrolysis. We further doubled the doses of hydrolytic enzymes to prehydrolyze an initial charge of $20 \%(w / v)$ carrot pomace for $12 \mathrm{~h}$; however, the maximum ethanol concentration was only $15 \mathrm{~g} / \mathrm{L}$ (at $72 \mathrm{~h}$ ) and the yield of ethanol from the carrot pomace was $0.075 \mathrm{~g} / \mathrm{g}$ (Table 1). We suspected that the low ethanol concentration and yield were related to the increased doses of Accellerase ${ }^{\mathrm{TM}} 1000$. We cultured $K$. marxianus $\mathrm{K} 21$ under different doses of Accellerase ${ }^{\mathrm{TM}} 1000$ at $42{ }^{\circ} \mathrm{C}$ (Figure 4). Our results indicated that the growth of the yeast was inhibited by the presence of Accellerase ${ }^{\mathrm{TM}} 1000$; such inhibition on $K$. marxianus has been reported by others [7]. Maximum ethanol concentrations, yields, and productivities using different fermentation strategies are summarized in Table 1.

\section{Experimental Section}

\subsection{Preparation of Carrot Pomace}

The juice of the carrots purchased from a local market was extracted with a juicer (Philips HR1861). The pomace was then collected and dried in an oven at $70{ }^{\circ} \mathrm{C}$ for 4 days. Dried pomace was ground, screened (20 mesh), and stored in a dark and dry environment at room temperature.

Figure 4. Effects of different doses of Accellerase ${ }^{\mathrm{TM}} 1000$ on the growth of Kluyveromyces marxianus $\mathrm{K} 21$ at $42{ }^{\circ} \mathrm{C}$. The doses were $0(\bullet), 5(\circ), 10(\boldsymbol{\nabla}), 15(\Delta)$ and $20(\mathbf{\square}) \mathrm{FPU} / \mathrm{g}$ dry matter.

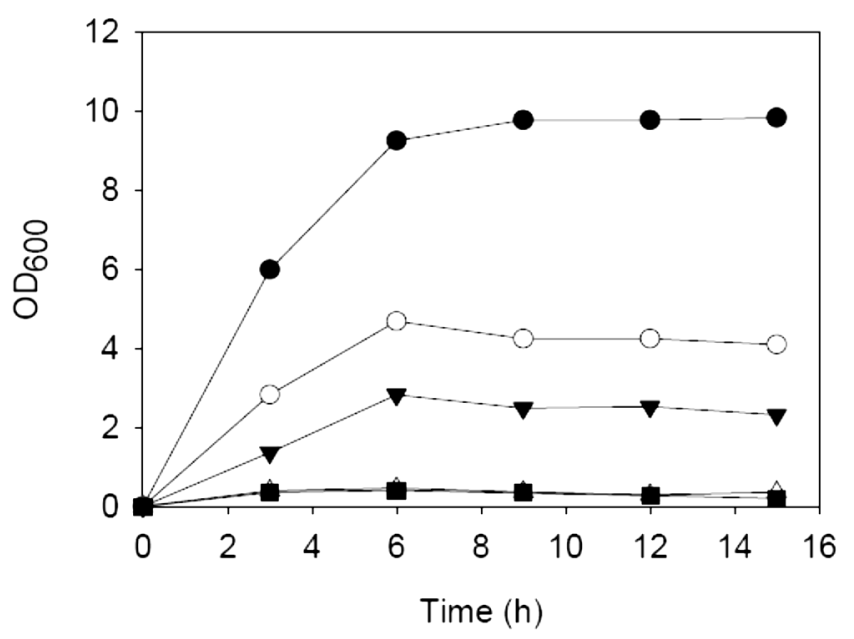

\subsection{Hydrolysis of Carrot Pomace}

Five\% $(w / v)$ suspension of carrot pomace $(100 \mathrm{~mL})$ was prepared with $50 \mathrm{mM}$ sodium citrate buffer, $\mathrm{pH}$ 5. The hydrolysis was initiated by the addition of Accellerase ${ }^{\mathrm{TM}} 1000$ (Genencor, Rochester, NY, USA) and pectinase (Sigma, St. Louis, MO, USA). Pectinase was used to enhance 
sugar conversion from carrot pomace in this study [11]. A pectin-hydrolyzing enzyme, has been used applied to enhance sugar conversion in rice straw treated with ammonia fiber expansion (AFEX) [12].

The doses of Accellerase ${ }^{\mathrm{TM}} 1000$ and pectinase were 15 filter paper unit (FPU)/g dry matter and $52.3 \mathrm{U} / \mathrm{g}$ dry matter, respectively. The hydrolysis was performed at $50{ }^{\circ} \mathrm{C}$ for $84 \mathrm{~h}$ on an orbital shaker at $150 \mathrm{rpm}$. The hydrolysate was heated to $95{ }^{\circ} \mathrm{C}$ to inactivate the enzymes. The hydrolysate was centrifuged at $14,000 \mathrm{rpm}$ for $10 \mathrm{~min}$, and then the supernatant was filtered with a $0.22 \mu \mathrm{m}$ filter. The composition of sugars in the hydrolysate was determined using high performance liquid chromatograph (HPLC) by comparing the retention time of the standards.

\subsection{Microorganism and Growth Conditions}

The thermotolerant yeast $K$. marxianus $\mathrm{K} 21$ was purchased from the Bioresource Collection and Research Center (Hsinchu, Taiwan). It was maintained on Yeast-Malt (YM) agar slant containing $10 \mathrm{~g} / \mathrm{L}$ glucose, $5 \mathrm{~g} / \mathrm{L}$ peptone, $3 \mathrm{~g} / \mathrm{L}$ yeast extract, $3 \mathrm{~g} / \mathrm{L}$ malt extract, and $20 \mathrm{~g} / \mathrm{L}$ agar. Active culture for inoculation was prepared in a $250 \mathrm{~mL}$ Erlenmeyer flask with $100 \mathrm{~mL}$ growth medium containing $30 \mathrm{~g} / \mathrm{L}$ glucose, $5 \mathrm{~g} / \mathrm{L}$ yeast extract, $2 \mathrm{~g} / \mathrm{L} \mathrm{NH}_{4} \mathrm{Cl}, 1 \mathrm{~g} / \mathrm{L} \mathrm{KH}_{2} \mathrm{PO}_{4}, 0.3 \mathrm{~g} / \mathrm{L} \mathrm{MgSO} 4 \cdot 7 \mathrm{H}_{2} \mathrm{O}$. The preculture was grown on a rotary shaker at $150 \mathrm{rpm}$ for $12 \mathrm{~h}$ at $40{ }^{\circ} \mathrm{C}$.

\subsection{SSF of Carrot Pomace}

The $450 \mathrm{~mL}$ SSF mixture containing $60 \mathrm{~g}$ of dried carrot pomace was prepared in a $1 \mathrm{~L}$ custom-made jar fermentor and then autoclaved at $121{ }^{\circ} \mathrm{C}$ for $30 \mathrm{~min}$. Ninety $\mathrm{mL}$ of medium containing $5 \mathrm{~g} / \mathrm{L}$ yeast extract, $2 \mathrm{~g} / \mathrm{L} \mathrm{NH} 4 \mathrm{Cl}, 1 \mathrm{~g} / \mathrm{L} \mathrm{KH}_{2} \mathrm{PO}_{4}$, and $0.3 \mathrm{~g} / \mathrm{L} \mathrm{MgSO}{ }_{4} \cdot 7 \mathrm{H}_{2} \mathrm{O}$ was added to the fermentor. After cooling down, $60 \mathrm{~mL}$ of $K$. marxianus $\mathrm{K} 21$ inoculum at $1 \times 10^{7} \mathrm{CFU} / \mathrm{mL}$ was added, followed by the addition of Accellerase ${ }^{\mathrm{TM}} 1000$ and pectinase; the doses were $15 \mathrm{FPU} / \mathrm{g}$ dry matter and $52.3 \mathrm{U} / \mathrm{g}$ dry matter, respectively. The final concentration of the carrot pomace was $10 \%(w / v)$. The initial $\mathrm{pH}$ was adjusted to 5 with $10 \mathrm{~N} \mathrm{NaOH}$. SSF experiments were performed at $680 \mathrm{rpm}$ and $42{ }^{\circ} \mathrm{C}$.

\subsection{Analytical Methods}

The composition of fermentable sugars was determined with a HPLC system equipped with a $\mathrm{NH}_{2}$-derivatized column (Chromatorex SPS-100-5, Fuji Silysia Chemical LTD, Kasugai, Aichi, Japan) and a refractive index detector (Shodex RI-201H, Showa Denko K.K., Minato-Ku, Tokyo, Japan). The mobile phase was $70 \%(v / v)$ acetonitrile at a flow rate of $0.5 \mathrm{~mL} / \mathrm{min}$. The column temperature was fixed at $30{ }^{\circ} \mathrm{C}$. The concentration of glucose was further measured with an YSI M2700 SELECT biochemistry analyzer (Yellow Springs, OH, USA). For the determination of ethanol concentrations, a Transgenomic ICSep ION-300 column (Omaha, NE, USA) was used in the HPLC system; the mobile phase was $0.0085 \mathrm{~N} \mathrm{H}_{2} \mathrm{SO}_{4}$ at a flow rate of $0.3 \mathrm{~mL} / \mathrm{min}$ and the column temperature was fixed at $50{ }^{\circ} \mathrm{C}$. All analyses were performed in duplicates.

\section{Conclusions}

Addition of $10 \%(w / v)$ carrot pomance at $12 \mathrm{~h}$ to an initial charge of $10 \%(w / v)$ of carrot pomace resulted in the highest ethanol concentration of $37 \mathrm{~g} / \mathrm{L}$ after $42 \mathrm{~h}$ with a yield of $0.185 \mathrm{~g} / \mathrm{g}$. The 
inclusion of a 12-h prehydrolysis step did not show an increase in the ethanol concentration, and increasing the dose of Accellerase ${ }^{\mathrm{TM}} 1000$ had an adverse effect on the growth of the yeast. Nevertheless, cellulases from different sources may alleviate the growth inhibition, leading to an even more efficient fermentation process. To test the possibility of applying such process to other feedstocks, in our preliminary study, ethanol concentration reached $17 \mathrm{~g} / \mathrm{L}$ after $96 \mathrm{~h}$ with $10 \%(w / v)$ orange peel as substrate and the yield was $0.17 \mathrm{~g} / \mathrm{g}$. Our results clearly indicate that the bioethanol production from carrot pomace using a SSF process combined with thermotolerant yeast is promising. Because of the fact that no pre-treatment such as steam explosion or AFEX is required, the overall process is much simplified, and thus reduces the capital cost for deriving bioethanol from carrot pomace.

\section{Acknowledgments}

Financial support from National Science Council (NSC98-2221-E-036-029; NSC 100-2221-E-036-025) and Ministry of Economic Affairs (98-EC-17-A-13-S1-116) of R.O.C. is gratefully acknowledged.

\section{References}

1. Margeot, A.; Hahn-Hagerdal, B.; Edlund, M.; Slade, R.; Monot, F. New improvements for lignocellulosic ethanol. Curr. Opin. Biotechnol. 2009, 20, 372-380.

2. Balat, M. Production of bioethanol from lignocellulosic materials via the biochemical pathway: A review. Energy Convers. Manag. 2011, 52, 858-875.

3. Yoon, K.Y.; Cha, M.; Shin, S.R.; Kim, K.S. Enzymatic production of a soluble-fibre hydrolyzate from carrot pomace and its sugar composition. Food Chem. 2005, 92, 151-157.

4. Nawirska, A.; Kwaśniewska, M. Dietary fibre fractions from fruit and vegetable processing waste. Food Chem. 2005, 91, 221-225.

5. Patle, S.; Lal, B. Ethanol production from hydrolysed agricultural wastes using mixed culture of Zymomonas mobilis and Candida tropicalis. Biotechnol. Lett. 2007, 29, 1839-1843.

6. Alfani, F.; Gallifuoco, A.; Saporosi, A.; Spera, A.; Cantarella, M. Comparison of SHF and SSF processes for the bioconversion of steam-exploded wheat straw. J. Ind. Microbiol. Biotechnol. 2000, 25, 184-192.

7. Tomás-Pejó, E.; García-Aparicio, M.; Negro, M.J.; Oliva, J.M.; Ballesteros, M. Effect of different cellulase dosages on cell viability and ethanol production by Kluyveromyces marxianus in SSF processes. Bioresour. Technol. 2009, 100, 890-895.

8. Sá-Correia, I.; Uden, N. Effects of ethanol on thermal death and on the maximum temperature for growth of the yeast Kluyveromyces fragilis. Biotechnol. Lett. 1982, 4, 805-808.

9. Matsuzaki, C.; Nakagawa, A.; Koyanagi, T.; Tanaka, K.; Minami, H.; Tamaki, H.; Katayama, T.; Yamamoto, K.; Kumagai, H. Kluyveromyces marxianus-based platform for direct ethanol fermentation and recovery from cellulosic materials under air-ventilated conditions. J. Biosci. Bioeng. 2012, 113, 604-607.

10. Zhao, J.; Xia, L. Simultaneous saccharification and fermentation of alkaline-pretreated corn stover to ethanol using a recombinant yeast strain. Fuel Process. Technol. 2009, 90, 1193-1197.

11. Jayani, R.S.; Saxena, S.; Gupta, R. Microbial pectinolytic enzymes: A review. Process Biochem. 2005, 40, 2931-2944. 
12. Zhong, C.; Lau, M.; Balan, V.; Dale, B.; Yuan, Y.-J. Optimization of enzymatic hydrolysis and ethanol fermentation from AFEX-treated rice straw. Appl. Microbiol. Biotechnol. 2009, 84, $667-676$.

(C) 2013 by the authors; licensee MDPI, Basel, Switzerland. This article is an open access article distributed under the terms and conditions of the Creative Commons Attribution license (http://creativecommons.org/licenses/by/3.0/). 